\title{
Research on the Safety Management of Recreational Fishing Ship
}

\author{
Tao Wang ${ }^{a}$, Yun-zi Geng ${ }^{b}$ and Shu-cui, Jiang ${ }^{c}$ \\ Shandong Jiaotong University maritime college, Weihai 264200, China \\ a hywangtao@126.com, b47285131@qq.com, ${ }^{\circ} 565347496 @ q q . c o m$
}

Keywords: Recreational fishing ship, safety management, Tourist caring, Crew

\begin{abstract}
Recreational fishing ship has its unique characteristics and needs special management. The research group analyzed problems of its management, such as lack of management regulations, confusion of supervision responsibilities, poor ship conditions, low management level, and poor professional knowledge of personnel. On this basis, a series of suggestions to promote the RF ship safety management are put forward, which including developing safety management regulations, scientific division of supervision responsibilities, regulating the access mechanism, encouraging business units to introduce scientific management modes, and strengthening the training of the crew.
\end{abstract}

\section{Introduction}

Benefited from a series of policies, recreational fishery gets the development at full speed in china. As an important and necessary carrier of the recreational fishery, recreational fishing ship (RF ship) must carry the tourist safely and comfortably, and provide fishing service for them. And it also has the responsibility of preventing marine pollution; protect marine ecology and fishery resources. So the management of RF ship has gradually attracted attention. Because such ship no longer belongs to traditional fishing ship or passenger ship, a new and efficient management mode must be developed.

\section{Analysis of Problems in the Management of RF Ship}

Regulations and standards on RF ship management are lacking. In recent years, the government began to pay attention to safety management of RF ship. Ministry of Agriculture (MOA) of China has stated clearly to strengthen the supervision and management of RF ship [1]. Under this policy, relevant local provisions have been issued in some developed regions. However, the national unified regulations and standards on safety management of RF ship are still blank.

Safety supervision responsibilities are not clear. According to current maritime law enforcement, the operation and management of RF ship are under the supervisions of Fishery Authorities, Administration of Traffic, Maritime Administration of Safety, Administration of safe work, Tourism Administration, and so on. Due to the lack of regulations on RF ship management, the responsibilities of those law enforcement agencies are not clear so as to the actual supervision is poor.

The overall condition of RF ships is poor. The RF ship resources and kinds are complex [2]. Many RF ships are refitted from old fishing vessels and their conditions are very poor, even some ships are not equipped with necessary lifesaving and communication equipments. Furthermore, a lot of unlicensed ships are also engaged in business activities.

The safety management level of business units is low. Current recreational fisheries business units in China include companies and individuals. The individuals, who derived from traditional fishermen, are lack of management experience especially the ship safety management experience. Fishery companies focus on the planning and management of the industry rather than ship management. Most companies are not manned with ship management personnel because there are not any mandatory requirements. Therefore, the overall safety management level of RF ship is very low.

Professional knowledge of crew and other employees are not competent. The educational level of crew and other employees are low and most of them do not get professional training, even some of them are not familiar with RF ship. They cannot ensure the safety of ship and tourists. 


\section{Suggestions on Improving the Safety Management of RF Ship}

In developed countries, e.g. United States, Argentina, Australia, recreational fishery began to embark on the track of standardized development from 1980s [3]. Many scientific and effective management modes have been applied to RF ship safety management, which are worth learning.

To make perfect safety management regulations for RF ship. According to the experience of recreational fishery development in the developed countries, safety management regulations of the RF ship are the most important [4]. Licensing system or access system had been established in those countries in the form of national legislation, so as to determine the management of RF ship from a legal perspective [5]. Therefore, Chinese fishery authorities shall develop nationwide RF ship safety regulations as soon as possible so that the RF ship management has its legal proof. In accordance with the characteristics of RF ship, regulations are suggested to be established from the following aspects.

Regulations for management of RF ship. It is the general basis for the management of RF ship. The regulations shall regulate the supervision and management responsibilities of RF ship. Meanwhile, the regulations shall make clear provisions about the business license, ship survey and registry, crew management, ship daily safety management and emergency management, etc.

Regulations for survey of RF ships. At present, the technical standards and survey requirements of RF ship are some regulations about fishing ships, e.g. "Statutory Survey Rules for Fishing Vessel”. However, these rules do not apply to ships which carry tourists, but only apply to general fishing vessels. "Statutory Survey Rules for RF Ship" shall be developed provided that the characteristics of RF ships are taken into account, especially carrying tourists.

Regulations for crew of RF ships. The service object of RF ships is tourist, and the crewmembers are responsible for ensuring the safety and comfort of tourists. Therefore, it is necessary to strengthen the management of the crew. The regulations shall include provisions of qualifications and registration, examination and certification, safety and work requirements.

To clarify the supervision responsibilities of the administrative departments. With regard to the RF ships supervision, most countries adopt the mode which the fishery authorities as the main, and other administrative departments as a supplement. In addition, a parallel administration and industry supervision mode is used. Some industry associations spontaneously participate in management [6].

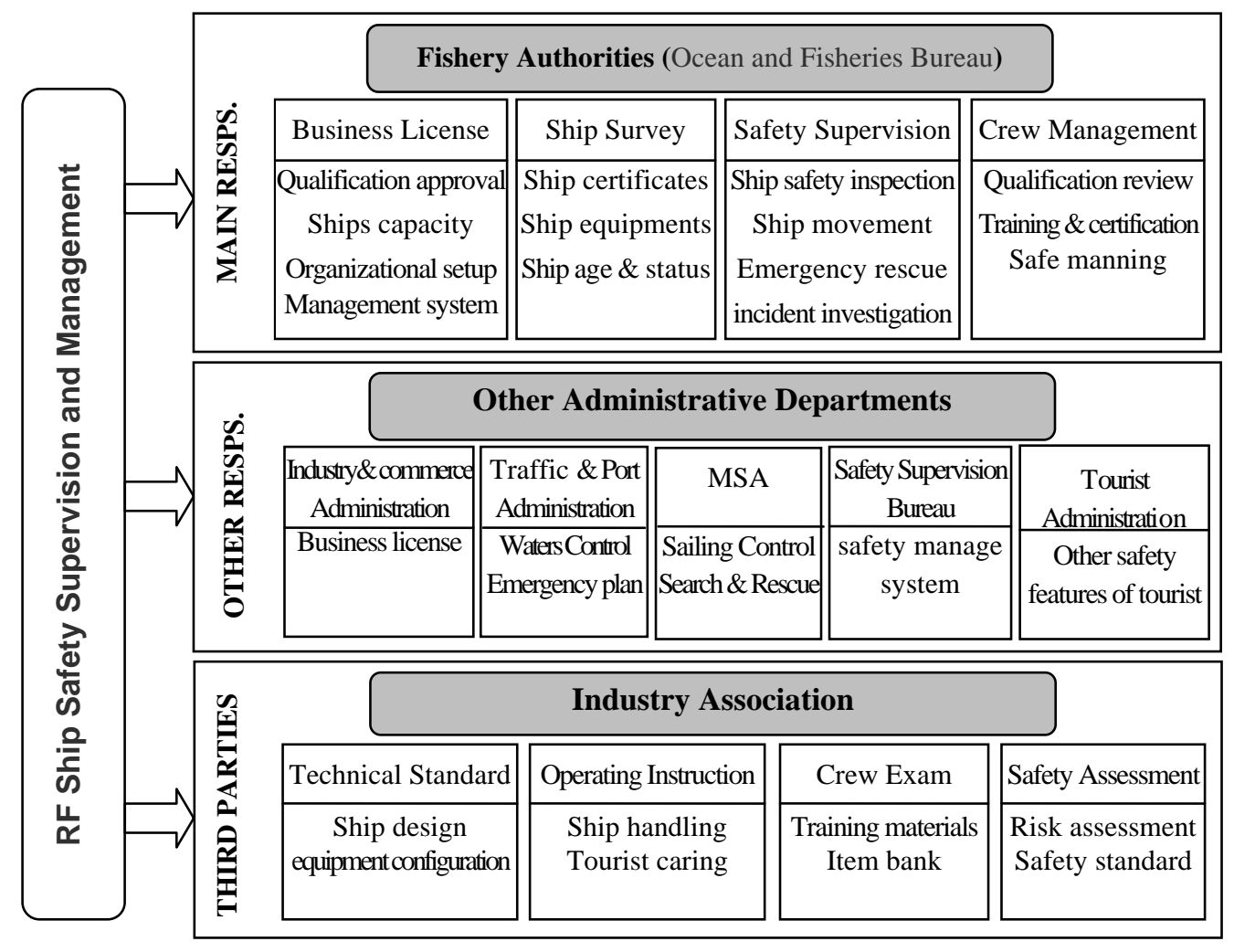

Fig.1 Division of supervision responsibilities of RF ships 
Referring to the general ship management modes and learning from the management modes of the developed countries, our research group suggested that the division of supervision responsibilities as shown in Fig. 1 on the basis of taking into account the special characteristics of the ship management.

To regulate the access mechanism of RF ships. This contains two aspects: the conditions of RF ship and her equipments, and the hardware and software facilities of the business units.

To promote standard RF ship type and obsolete old ship gradually. Professionals generally believe that the promotion of standard ship type is an effective way to develop RF ship. Some ship types have been reviewed, finalized, and put into use in some provinces. Fishery authorities should organize industry associations and experts to develop and refine RF ship design standards so as to further enrich the standard ship types. As for ship design and layout, the comfort and safety should be fully highlighted. At the same time, leisure fishing, water tourism, aquarium appreciation, fishery experience and other diverse requirements should be fully considered.

The authorities shall strengthen the publicity and promotion of the standard ship, and encourage business units to purchase or build standard ship with subsidies. In addition, it is advised that a transition period shall be set up to obsolete old ships gradually.

To regulate the qualification approval process of business units. The fishery authorities should attach importance to the development capacity and quality of recreational fishery. When approving the qualification of business unit, the fishery authorities shall check the conditions of RF ships and equipments, and what's more, they shall check strictly the manning of professional safety officers, the practicability of safety management system and t safe operating procedures, and so on.

To introduce scientific concept and model of ship management. As the main body of safety responsibility, business units should learn advanced concepts and introduce scientific management mode actively. "Safety Management System"(SMS) and "Safety Standardization System" (SSS) is the most common ship management modes. Using SMS and SSS for reference, it is recommended that the business units should strengthen the RF ship management from the following aspects.

To perfect management organization and personnel According to the Production Safety Law and other regulations, RF ship business units shall set up safety organization and be manned with professional safety management personnel. After a clear division of responsibilities, the unit should implement the responsibility system for production safety. It should be emphasized that the man who is responsible for the ship's safety management must hold a master certificate of RF ship and have practical experience in navigation. In addition, the unit should be manned with sufficient qualified crewmembers and other employees by the ship inspect certificate.

To establish practical ship safety management system and operating procedures. The RF ship safety management system shall at least include: Ship and equipments management system, Ship navigation safety management system, Tourist fishing and safety management system, Marine environmental protection and pollution prevention management system, Ship emergency management system, Safety training system for crew and employees.

The RF ship safety operating procedures shall at least include: Ship starting and steering procedure, Ship berthing procedure, Ship safety operating procedure under special weather conditions, Tourist safety care operation procedure, and Safety operation procedures for all marine equipments.

To enhance the training for crew and other employees. RF ship crewmembers are required to hold relevant fishing crew certificates by fishery authorities. Because RF ships are small, crew certificate needs only level 3 or below in accordance with China certification regulations. These crewmembers have poor knowledge and skill; even many of them are not familiar with ship and navigation. In addition, they do not get any training of tourist caring and management. As for other employees, there are not any certification requirements for them and their skills are lower. Furthermore, taking into account the regional characteristics of RF ship, the crew and employees should also master some knowledge about the local hydrological, meteorological and local regulatory requirements. The research group was commissioned by the local fishery authorities to develop pre-post training program for crew and employees, which is in Table 1. Practice shows that the professional qualities and skills of the crew and employees have been greatly improved after they received such training. 
Table 1 Pre-post training program for crew and employees of RF ship

\begin{tabular}{|c|c|c|}
\hline \multirow{2}{*}{ Training Contents } & \multicolumn{2}{|c|}{ Period Distribution } \\
\hline & Theory & Practice \\
\hline 1 Navigation Rules and Safety Regulations & 2 & \\
\hline 1.1 Navigation rules of the coastal waters and local regulations & 1 & \\
\hline 1.2 Laws and regulations of recreational fishery & 1 & \\
\hline 2 Basic Knowledge of Navigation and Handling of RF Ships & 6 & 3 \\
\hline 2.1 General operation of navigation and ship handling & 1 & \\
\hline 2.2 Ship berthing and anchoring & 1 & 1 \\
\hline 2.3 Navigation in special cases (thunderstorm, fog, mechanical failure, etc.) & 1 & \\
\hline 2.4 Emergency ship handling (man overboard, flooding, collision, fire, etc.) & 1 & \\
\hline 2.5 The use of equipments and riggings & 2 & 2 \\
\hline 3 Basic Safety Knowledge of RF Ships & 6 & 3 \\
\hline 3.1 Fire preventing and fighting on RF ships & 2 & 1 \\
\hline 3.2 The use of life saving equipment and marine survival skills & 2 & 1 \\
\hline 3.4 Basic knowledge of first aid & 2 & 1 \\
\hline 4 Tourist Safety Management and Emergency Procedures & 6 & 2 \\
\hline 4.1 Post duty and emergency arrangement & 1 & \\
\hline 4.2 Tourist care on board & 2 & \\
\hline 4.3 Emergency management and control of tourists & 2 & 2 \\
\hline 4.4 Security and anti-terrorism of RF ships & 1 & \\
\hline 5 Marine Environment Protection and Ecological Protection & 4 & \\
\hline 5.1 Rules on the protection of marine environment and fishery resources & 1 & \\
\hline 5.2 Anti-pollution on board (anti-pollution equipment, garbage disposal, etc) & 2 & \\
\hline 5.3 Emergency measures to pollution accident & 1 & \\
\hline Total & 24 & 8 \\
\hline
\end{tabular}

\section{Summary}

A consensus has been reached in the industry that it is necessary to strengthen RF ship management to meet the rapid development of recreational fishery. Based on establishing RF ship safety management regulations, administrative authorities can be clearly aware of their own supervision responsibilities and carry on effective management. As the third party, industry associations can not only provide technical support for RF ship management, but also give reasonable evaluation to the administrative authorities. RF ship industry will develop healthy and orderly due to concerted efforts of all parties.

\section{Acknowledgements}

This research was supported by Foundation of Shandong Jiaotong University (No. Z201504). Thanks to the experts for discussion and help.

\section{References}

[1] Chin MOA. Opinions on promoting the sustainable and healthy development of recreational fishery. (2012-12-13). http://www.moa.gov.cn

[2] Xingwu Zhao. Shandong recreational fishery development is in the ascendant. China Fisheries, 6(2015)16-19

[3] Hongxian Yu. Recreational Fishery. Northeast Forestry University Press, 2009

[4] Ying Ping, Jie $\mathrm{Xu}$, Peng Wang. The basic experience of the development of recreational fishery in the developed countries. World Agriculture, 4(2015) 25-28

[5] Shousheng Chai, Jiajia Zhang. Enlightenment from the development of leisure fishery in the United States and Japan to the development of leisure fishery in China. Periodical of Ocean 
University of China, 1(2007) 27-31

[6] Robert M. Hughes. Recreational fisheries in the USA: economics, management strategies, and ecological threats. Fisheries Science, 81(2015) 1-9 